\title{
PENYULUHAN TIPS DAN TRIK PENGGUNAAN E- COMMERCE UNTUK PENGEMBANGAN UMKM MASYARAKAT DESA SIDOMULYO KECAMATAN SEMBORO KABUPATEN JEMBER DI ERA PANDEMI COVID-19
}

\author{
Ahmad Sauqi ${ }^{1}$ \\ ${ }^{1}$ Jurusan Manajemen , STIE Mandala Jember \\ e-mail: sauqi@stie-mandala.ac.id
}

\begin{abstract}
This service seeks to solve the problems of MSMEs in Sidomulyo village by providing counseling on the theme of tips and tricks for using e-commerce for community development in Sidomulyo Village, Semboro District, Jember Regency in the era of the Covid-19 pandemic. The results of this trial included the MSME community in the village of Sidomulyo Semboro Jember stated that their products were selling well compared to before the existence of E-Commerce counseling, MSME players in Sidomulyo Village stated that they had started a lot of these things they felt by ordering them. more and more every week. MSME players in Sidomulyo Village stated that marketing products through E-Commerce is easy if you learn to just post in the Facebook buying and selling group, put it on the Facebook market place or sell it through shopee or tokopedia.
\end{abstract}

Keywoard: Tips; Tricks; E-Commerce; UMKM; Sidomulyo

\section{PENDAHULUAN}

Pengabdian kepada masyarakat sendiri telah tertuang dalam Tri Dharma Perguruan Tinggi yaitu pendidikan dan pengajaran, penelitian, dan pengabdian kepada masyarakat. Oleh karena itu, setiap Perguruan Tinggi termasuk STIE Mandala Jember memiliki komitmen untuk melaksanakan Tri Dharma Perguruan Tinggi. Salah satu aplikasi pengabdian kepada masyarakat termanifestasikan dalam Pengabdian Kepada Masyarakat.

Selanjutnya, salah satu bagian dari masyarakat yang perlu mendapatkan perhatian adalah pengembangan sumber daya masyarakat. Dalam peninjauan terhadap lokasi yang diinginkan menjadi tempat pengabdian kepada masyarakat harus memerhatikan beberapa kondisi masyarakat, diantaranya keagamaan, pendidikan, ekonomi/ kewirausahaan, lingkungan, dan kesehatan. Sehingga, dalam pemilihan dan pengajuan Desa/ kelurahan pengabdian kepada masyarakatperlu diperhatikan kondisi dan persoalan yang ada dalam masyarakat untuk merumuskan program kerja dan kegiatan. 
Desa Sidomulyo merupakan salah satu Desa yang berada di kecamatan Semboro sebagian besar wilayahnya adalah area persawahan yang subur dan lingkungan alam yang asri. Mayoritas mata pencaharian warga Sidomulyo adalah petani di Desa Sidomulyo juga terdapat masyarakat yang bermata pencaharian dalam budi daya ikan lele, ikan gurami serta budidaya bibit tanaman yang di kelola oleh UMKM setempat, namun saat ini ada masalah terkait lesunya penjualan produk ditambah lagi di era pandemi Covid-19 ini. Adapun keadaan lingkungan sudah cukup bersih dan tertata rapi namun kebanyakan masyarakat di sana para pelaku UMKM nya sedang kesulitan dalam memasarkan produk hasil produksi mereka mulai dari produk hasil pembibitan ( bunga, jeruk dan lain lain ), hasil budidaya ikan, serta hasil berbagai usaha skala rumahan yang biasanya dikerjakan oleh para ibu rumah tangga.

Desa Sidomulyo dapat dikatakan sebagai salah satu lokasi yang cocok untuk pelaksanaan pengabdian kepada masyarakat yang diselenggarakan oleh Lembaga Pusat Penelitian dan Pengabdian pada Masyarakat (P3M) STIE Mandala Jember dengan menugaskan para dosen-dosennya yang memiliki kompetensi untuk mengatasi permasalahan yang ada di desa ini. Berdasarkan survei awal yang sudah kami lakukan di desa Sidomulyo dengan secara langsung berkomunikasi dengan kepala desanya maka dapat kami pahami bahwa intinya di desa ini sedang membutuhkan pengembangan strategi pemasaran produk yang di hasilkan terlebih pada masa pandemi ini.

Menurut Heizer ( 2011:18) produktifitas adalah perbandingan antara output ( barang dan jasa ) dibagi dengan input ( sumber daya seperti tenaga kerja dan modal ). Di Desa Sidomulyo masyarakatnya secara umum sangat produktif minimal di bidang pertanian. Dari hasil kunjugan lapang produk-produk hasil olahan UMKM di desa Sidomulyo sudah cukup berkualitas hal ini terbukti dari hasil pembibitan bunga yang tingkat hidupnya tinggi, kualitas sendiri menurut Tjiptono ( 2011 : 171 ) kualitas lebih menekankan aspek kepuasan pelanggan dan pendapatan dengan fokus utamanya adalah customer utility. Pengembangan pasar baru memang harus dilakukan oleh masyarakat pelaku UMKM di desa Sidomulyo karena pasar lama terkaang jenuh intinya diversifikasi perlu dilakukan, diversifikasi sendiri merupakan upaya mencari dan mengembangkan produk atau pasar yang baru, atau keduanya dalam rangka mengejar pertumbuhan , peningkatan penjualan, profitabilitas dan fleksibilitas ( Tjiptono, 2008 : 132 ). Masyarakat pelaku UMKM di desa Sidomulyo juga sedikit memahami terkait lonjakan perminataan produk hasil produksi mereka tapi di masa pandemi ini mereka semakin sulit meramalkannya, peramalan itu memang perlu dilakukan, peramalan sendiri merupakan pengetahuan dan seni untuk memperkirakan apa yang akan terjadi di masa yang akan datang pada saat sekarang ( Kasmir, 2012:61 ). 
Berdasarkan analisis situasi yang telah di paparkan sebelumnya dapat kami sepakati bersama dengan Kepala Desa Sidomulyo dan pelaku UMKM di desa tersebut terkait penentuan masalah utama yang dihadapi. Adapun permasalahan utama tersebut meliputi:

Produk hasil produksi UMKM di desa Sidomulyo ini di masa pandemi Covid-19 mengalami penurunan penjualan sehingga mereka mengalami banyak kerugian khususnya pelaku usaha di bidang pembibitan, peternakan ikan dan usaha skala rumahan yang dikerjakan oleh para ibu rumah tangga di sana. Pemahaman pelaku usaha di desa Sidomulyo terkait strategi pemasaran masih kurang sehingga pemasaran selama ini hanya dilakukan kepada beberapa pelanggan saja yang tentunya harganya cenderung relatif murah. Penggunaan teknologi informasi dalam hal E-Commerce masih sangat minim sehingga perluasan pasar belum maksimal.

Secara ringkas permasalahan dari UMKM di desa Sidomulyo Semboro adalah produk hasil produksi UMKM di desa Sidomulyo ini di masa pandemi Covid-19 mengalami penurunan. Pemahaman pelaku usaha di desa Sidomulyo terkait strategi pemasaran masih kurang. Penggunaan teknologi informasi dalam hal E-Commerce masih sangat minim sehingga perluasan pasar belum maksimal. Atas permasalahan ini kami dari pihak pengabdi ( Dosen STIE Mandala ) melalui penugasan dari UPT P3M STIE Mandala akan memberikan penyuluhan secara ringkas padat dan jelas sehingga para pelaku usaha di desa ini dapat segera memahaminya secara cepat meskipun hanya dalam kurun waktu 1 bulan penyuluhan yang secara efektifnya kami lakukan secara offline dengan tetap mengikuti protokol kesehatan sesuai anjuran permerintah dan penyuluhan online melalui media zoom.

Menurut kami ketiga permasalahan tersebut bisa diselesaikan satu persatu dan untuk itu yang utama kami akan mengadakan penyuluhan dengan tema tips dan trik penggunaan e-commerce untuk pengembangan umkm masyarakat Desa Sidomulyo Kecamatan Semboro Kabupaten Jember di era pandemi covid-19. Intinya perluasan pasar itu harus dilakukan karena sebaik apapun hasil produksi namun tidak terjual maka ini akan menjadi masalah bagi para pelaku usaha itu sendiri

Berdasarkan pada poin analisis situasi dan permasalahan mitra maka pengabdi dapat mengusulkan solusi kepada UMKM di Desa Sidomulyo Kecamatan Semboro Kabupaten Jember sebagai berikut: Penyuluhan mengenai strategi manajemen pemasaran yang mengacu pada revolusi industri 4.0. Penyuluhan mengenai strategi pemasaran fokus pada menjaga hubungan baik dengan pelanggan lama dan bagaimana mendapatkan pelanggan baru dengan memanfaatkan teknologi informasi. Penyuluhan strategi pemasaran dengan penenkanan pada pelaksanaan pemasaran melalui E-Commerce. 
Berdasarkan 3 solusi yang ditawarkan tersebut dapat kami rangkum penyuluhan ini dengan tema penyuluhan tips dan trik penggunaan e-commerce untuk pengembangan umkm masyarakat Desa Sidomulyo Kecamatan Semboro Kabupaten Jember di era pandemi covid-19.

Rencana target capaian luaran dari solusi yang ditawarkan kepada UMKM di Desa Sidomulyo dapat dilihat pada tabel 1 sebagai berikut ini.

Tabel 1 Rencana Targer Capaian

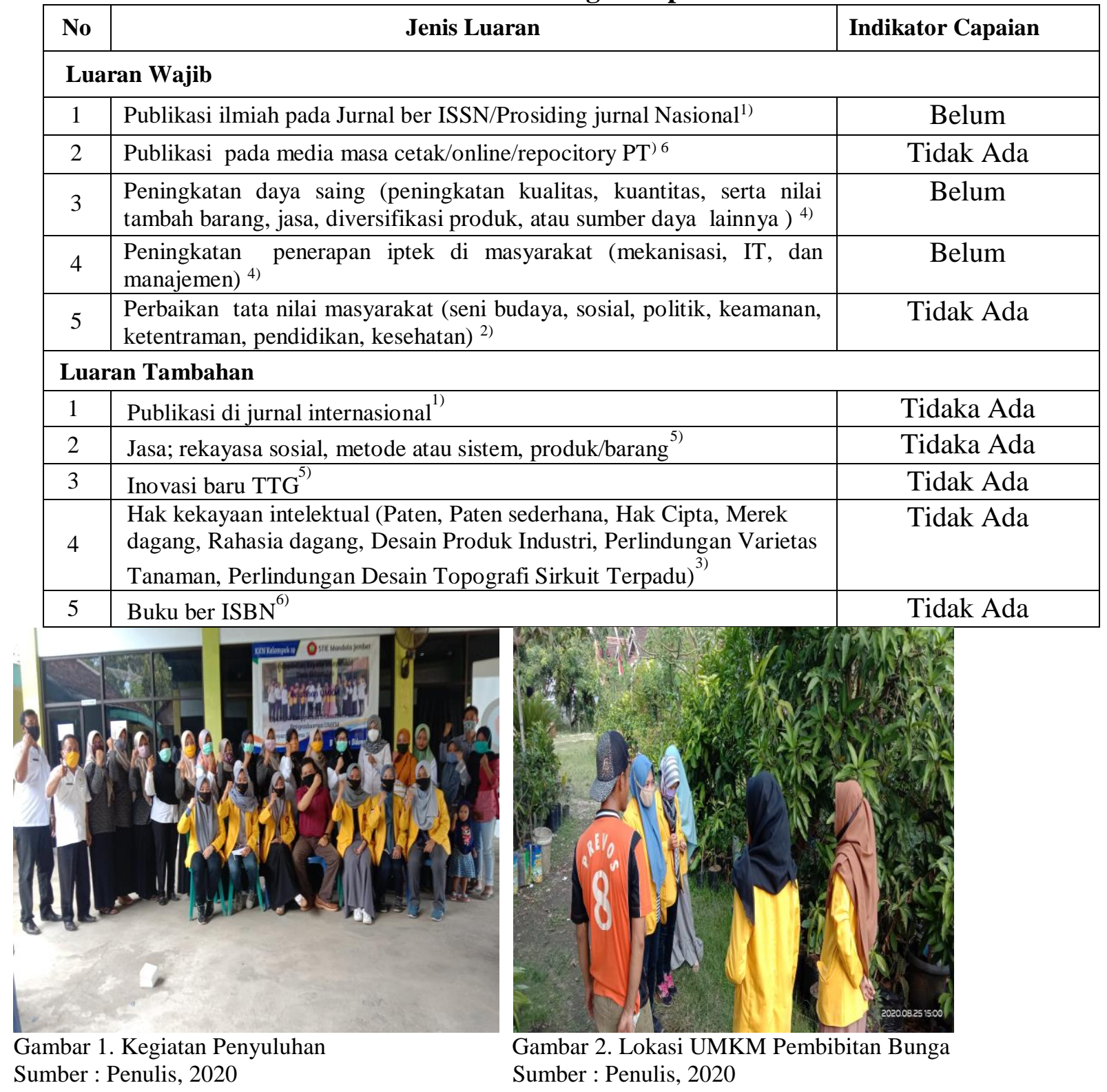




\section{METODE}

Penawaran solusi untuk UMKM di Desa Sidomulyo antara lain memberdayakan pelaku usaha terkategori UMKM di desa Sidomulyo dengan memberikan penyuluhan mengenai strategi manajemen pemasaran yang mengacu pada revolusi industri 4.0, Memberdayakan pelaku usaha terkategori UMKM di desa Sidomulyo dengan memberikan penyuluhan mengenai strategi pemasaran fokus pada menjaga hubungan baik dengan pelanggan lama dan bagaimana mendapatkan pelanggan baru dengan memanfaatkan teknologi informasi dan memberdayakan pelaku usaha terkategori UMKM di desa Sidomulyo dengan memberikan penyuluhan strategi pemasaran dengan penenkanan pada pelaksanaan pemasaran melalui E-Commerce.

Metode pendekatan yang ditawarkan untuk menyelesaikan permasalahan UMKM di Desa Sidomulyo dengan melakukan pelatihan-pelatihan dalam bentuk forum diskusi baik onffline atau online melalui zoom dan pendampingan dengan menggunakan metode learning by doing sebagai tindak lanjut pembekalan yang telah dilakukan.

Partisipasi mitra dalam pelaksanaan program PKM ; Pelaku UMKM di Desa Sidomulyo berperan aktif ( menghadiri undangan kegiatan penyuluhan ). Pelaku UMKM di Desa Sidomulyo bersedia menyempatkan waktu untuk mengikuti penyuluhan dan pendampingan sesuai dengan jenis penyuluhan yang sudah di sebutkan sebelumnya,antar lain : Penyuluhan mengenai strategi manajemen pemasaran yang mengacu pada revolusi industri 4.0 Penyuluhan mengenai strategi pemasaran fokus pada menjaga hubungan baik dengan pelanggan lama dan bagaimana mendapatkan pelanggan baru dengan memanfaatkan teknologi informasi. Penyuluhan strategi pemasaran dengan penenkanan pada pelaksanaan pemasaran melalui E-Commerce.

Evaluasi pelaksanaan program dan keberlanjutan program di lapangan setelah kegiatan pengabdian selesai dilaksanakan. Penilaian kesuksesan dari program pengabdian terhadap UMKM di desa Sidomulyo sangat perlu dilakukan agar tujuan utama dari adanya program ini benar-benar berhasil yakni meningkatnya perekonomian masyarakat serta berkembangnya usaha mikro dari masyarakat itu sendiri. Evaluasi dari pelaksanaan program pengabdian ini adalah Mengukur kesuksesan UMKM di desa Sidomulyo menjalankan strategi pemasaran berbasis E-Commerce sehingga dapat meningkatkan penjualan dan dapat mendapatkan pelanggan baru atau pembeli baru. Keberlanjutan dari pelaksanaan program pengabdian ini adalah kami selaku pengabdi akan berkunjung untuk melihat kondisi UMKM setelah mendapatkan penyuluhan

\section{HASIL DAN PEMBAHASAN}

Berdasarkan informasi yang kami dapatkan dari desa Sidomulyo yakni 
dari bapak kepala Desa dan masyarakat pelaku UMKM di sana setelah adanya kegiatan penyuluhan yang kami lakukan mereka sedikit banyak sudah merasakan manfaatnya, adapun manfaatnya antara lain yang mereka nyatakan adalah sebagai berikut: Pelaku UMKM di Desa Sidomulyo menyatakan bahwa pemasaran produk hasil produksi mereka sudah cukup laku keras dibandingkan sebelum adanya penyuluhan, mereka merasa menjual secara online itu menyenangkan dan pembelinyapun bisa dari daerah luar kota. Pelaku UMKM di Desa Sidomulyo menyatakan bahwa pelanggan sudah mulai banyak hal ini mereka rasakan dengan adanya pemesanan yang semakin banyak di setiap mingggunya. Pelaku UMKM di Desa Sidomulyo menyatakan bahwa memasarkan produk melalui E-Commerce ternyata mudah kalau di perlajari tingggal posting di group jual beli facebook, taruh di market place facebook atau di jual melalui shopee ataupun tokopedia. Luaran yang dicapai berupa artikel yang akan dipublish pada jurnal pengabdian dan pelaku UMKM di Desa Sidomulyo yang sudah mampu memanfaatkan Teknologi Informasi untuk memasarkan produk hasil produksinya.

\section{KESIMPULAN}

Berdasarkan hasil dari kegiatan pengabdian ini maka dapat disimpulkan bahwasanya kemampuan dalam memproduksi atau menciptakan produk baik barang ataupun jasa yang didukung dengan kemampuan penggunaan tekologi informasi akan mendukung kelancaran pemasaran produk yang sudah diproduksi dan hal ini sudah terbukti di mana masyarakat pelaku UMKM di desa Sidomulyo Semboro Jember menyatakan bahwa produk hasil produksi mereka sudah cukup laku keras dibandingkan sebelum adanya penyuluhan E-Commerce, Pelaku UMKM di Desa Sidomulyo menyatakan bahwa pelanggan sudah mulai banyak hal ini mereka rasakan dengan adanya pemesanan yang semakin banyak di setiap mingggunya. Pelaku UMKM di Desa Sidomulyo menyatakan bahwa memasarkan produk melalui E-Commerce ternyata mudah kalau di pelajari tingggal posting di group jual beli facebook, taruh di market place facebook atau di jual melalui shopee ataupun tokopedia.

\section{DAFTAR PUSTAKA}

Heizer, Jay \& Barry Render. 2009. Manajemen Operasi Buku 1. Edisi 9. Salemba Empat. Jakarta.

Kasmir, Jakfar. 2013. Studi Kelayakan Bisnis. Edisi 9. Kencana Prenanada Group. Jakarta.

Kotler, Philip. 2009.Manajemen Pemasaran.Edisi 13 Jilid 2 . Edisi Terjemahan Oleh Bob Sabran. Erlangga. Jakarta.

Tjiptono, Fandy. 2008. Strategi Pemasaran. Edisi 3. Andi Offset. Yogyakarta. 
Jurnal Pengabdian Masyarakat, Vol.1 No.1, Februri 2021, hlm. 1-7

Tjiptono, Fandy.2011. Service, Quality \& Satisfaction. Edisi 3. Andi Offset. Yogyakarta. 